\title{
Self-efficacy and Critical Thinking of Novice and Experienced EFL Teachers: A Sequential Mixed Methods Study
}

\section{Mojgan Rashtchi}

TEFL Department, Faculty of Foreign Languages, North Tehran Branch, Islamic Azad University, Tehran, 1651153311, Iran

\begin{abstract}
Self-efficacy and critical thinking (CT) contribute to teachers' successful performance in their profession and can ultimately develop the education system of society. The researcher designed a sequential explanatory mixed methods study to follow three objectives in exploring practical opportunities for EFL teacher development. First, it examined the relationship between SE and CT of novice and experienced teachers. Next, it investigated whether the two groups differed in the two variables. Third, it explored whether an instruction on CT skills could promote teachers' thinking skills and self-efficacy. The results of Pearson's r showed a positive correlation between the two dispositions. However, no statistically significant differences were found between the CT and self-efficacy of the groups. In the second phase, a quantitative study with a static group comparison design was followed by a qualitative study that investigated participants' improvement after receiving training on thinking skills. The results of the Multivariate Analysis of Variance (MANOVA) indicated statistically significant differences between the groups'

ARTICLE INFO

Article history:

Received: 29 April 2020

Accepted: 6 August 2020

Published: 26 March 2021

DOI: https://doi.org/10.47836/pjssh.29.1.01

E-mail address:

mojgan.rashtchi@gmail.com self-efficacy and CT. At the final step, volunteers from the experimental group were interviewed to clarify the results obtained from the quantitative phase. The study has implications for teachers and teacher trainers.

Keywords: Critical thinking, EFL teachers, selfefficacy, thinking strategies
\end{abstract}




\section{INTRODUCTION}

Any educational system owes its success mostly to the productive role teachers play in the process of teaching and learning. Teachers' lack of motivation, efficiency, and self-reflection can lead to the system's failure and may affect society as teachers are responsible for the education of future citizens (Lipman, 2003). Thus, internal processes that shape teachers' behavior among which stands the sense of selfefficacy is worthy of attention. Selfefficacy reflects the extent of one's belief in achieving a goal and affects the way a person thinks, acts, and encourages himself/herself (Bandura, 1977). In education, self-efficacy refers to one of the motivation expectancy components and describes the extent to which an individual believes s/he can accomplish a particular task (Pintrich \& De Groot, 1990), or is prepared to do a specific action (Bandura, 1995; Zimmerman, 2000). Thus, self-efficacy is the basis of "beliefs in one's capabilities to organize and execute the courses of action required to produce given attainments" (Bandura, 1997, p. 3).

On the other hand, self-efficacy and critical thinking (CT) involves higherorder thinking skills and is the supreme by-product of an educational system. Researchers agree that education can benefit from the inclusion of CT in its curricula, which would be possible only when teachers equipped with $\mathrm{CT}$ ability do their best to cultivate learners' thinking skills (Lipman, 2003; Synder \& Synder, 2008). As a social and emotional ability, CT consists of seeking the truth, being open-minded, systematic, analytic, mature, inquisitive, and self-confident. These characteristics, if possessed, can portray most of the features an ideal teacher should have. Therefore, the presence of a relationship between $\mathrm{CT}$ with many of the attributes of successful teachers is predictable. However, since CT is not a natural disposition possessed by all individuals and is a learnable ability (Schafersman, 1991), the existence of a causal relationship indicating that instruction on the improvement of thinking skills can affect teacher characteristics is thoughtprovoking. The finding that teaching CT skills can improve teachers' self-efficacy might be illuminating for educators seeking to promote the quality of education. Such a conclusion may draw educators and teacher trainers' attention to consider CT as one of the components of teachers' knowledge base (see Koehler \& Mishra, 2009). It may encourage thinking skills in pre-service and in-service teacher training courses.

Accordingly, the present study followed three purposes. First, it aimed to examine whether there was a relationship between self-efficacy, as the characteristic teachers need to act successfully in their career, and CT of novice and experienced teachers. Considering years of expertise was vital since it could reveal whether years of involvement in the teaching profession per se could affect teachers' sense of self-efficacy and thinking skills. Therefore, as a second objective, it investigated the difference between the self-efficacy and CT of the groups. The findings would underscore the role of teacher training courses regardless 
of the years of teaching experience. Third, it explored whether practicing thinking skills could have an impact on the two variables under scrutiny. The finding could be illuminating for policymakers regarding including thinking skills practices in teacher training courses.

A close look into the definitions of self-efficacy and $\mathrm{CT}$ reveals that both involve reflection. That is to say, selfefficacy enables teachers to self-reflect; and allows individuals to "symbolize, learn from others, plan alternative strategies, regulate one's own behavior, and engage in self-reflection" (Pajares, 1996, p. 543). Additionally, as Dewey (1933, pp. 5657) argued, reflective teaching requires "establishing conditions that will arouse and guide curiosity; of setting up the connections in things experienced that will on later occasions promote the flow of suggestions, create problems and purposes that will favor consecutiveness in the succession of ideas" (italics in original). Thus, the two concepts can lead to the professional development of teachers. However, although several researchers have advocated the direct teaching of thinking skills (Lipman, 1984; Paul, 1995) self-efficacy, as Pajares (1996) argued, is the predictor of human behavior which, in turn, is the outcome of the interaction of different factors and thus not teachable.

The domain of language teaching (EFL/ESL) has also witnessed a focus on the concept of reflective teaching since the 1990s (Kumaravadivelu, 2003). Language teachers are supposed to have a critical view toward their profession and reason about the way they "conceptualize, construct explanations for, and respond to the social interactions and shared meanings that exist within and among teachers, students, parents, and administrators, both inside and outside the classroom" (Johnson, 1999, p. 1). Reflective language teachers are expected to evaluate themselves and their actions in the classroom and build their skills over time. These responsibilities require language teachers to be problem-solvers and decisionmakers and thus deal with CT issues. The idea that by practicing thinking skills EFL teachers can enhance their self-efficacy establishes the significance of the present study.

\section{LITERATURE REVIEW}

\section{Self-efficacy}

The theoretical framework of self-efficacy uncovers its origins in Bandura's (1977) assertion that what people think, believe, and feel about themselves can affect their behavior in social settings. Self-efficacy lets individuals evaluate their ability to do tasks at a specific time and obtain the desired outcome as a result of one's effort (Bandura, 1986; Pajares, 1996). Thus, teachers' self-efficacy could be the reason for the significant differences in learners' performances of the same knowledge and skill (Bandura, 1986) or the difference in student's achievements (Bouffard-Bouchard, 1990).

Furthermore, as Bandura (1986, 1997) puts it, teachers with a higher sense of self-efficacy own more elevated levels of 
self-confidence and improve the teaching and learning environment. Success in implementing classroom practices relies on teachers' view of their capability to deal with the challenges they encounter in their classes. Research indicates that teachers with high levels of self-efficacy are more flexible, have a higher willingness to change their teaching methods, and show more interest in their profession (e.g., Allinder, 1994; Guskey, 1988; Tschannen-Moran \& Hoy, 2001).

Many studies have focused on teacher self-efficacy and have shown its relationship with different aspects of the teaching profession. For example, Schwab (2019) found a positive correlation between teachers' general self-efficacy and studentspecific self-efficacy. The studies by Marashi and Azizi-Nassab (2018), and Rashtchi and Jabalameli (2012) revealed that the level of language proficiency and using different language teaching strategies increased with high degrees of self-efficacy. Swanson's (2012) study indicated that self-efficacy negatively correlated with professional attrition. Likewise, Chacón's (2005) survey of 100 EFL instructors' sense of efficacy in Venezuelan middle schools showed a correlation between teachers' perception of their self-efficacy and their self-reports regarding their knowledge of culture and the four English language skills. The study by Rodríguez et al. (2009) underscored the role of self-efficacy in motivation and professional involvement of Spanish university teachers. Although these studies explored the relationship between self- efficacy and different variables, one factor was common among them: the constructive role of self-efficacy in teachers' professional performance. The present study was one step beyond correlational studies and intended to explore whether training in $\mathrm{CT}$ could affect teachers' self-efficacy.

\section{Critical Thinking}

The origins of CT can be traced back to 2000 years ago when Socrates used cooperative dialogues to answer his students' questions, and thus cultivate their thinking skills. Dewey regarded it as an active process by which individuals think about a phenomenon, ask questions from themselves, and attempt to find answers rather than look for information from someone else (Fisher, 2001). Therefore, CT is the ability to evaluate, reason, and find evidence to support the reasons (Lipman, 2003).

The components of CT, as identified by the Delphi Project in the 1980s, was that it is "purposeful, self-regulatory judgment which results in interpretation, analysis, evaluation, and inference" (Facione, 1990, p. 2). Paul's (1995) definition as the ability to think about thinking underscores the role of metacognition in CT and clarifies how reflection and critical thinking merge. Paul (1993) differentiated between aimless thinking and purposeful thinking and argued that purposeful thinking helped individuals discovered, solved problems, and reasoned. If individuals can engage in purposeful thinking, they can achieve goals, undertake acts, and appear efficient. 
Some studies have addressed EFL teachers' CT and have sought to find its relationship with teaching success or self-efficacy (e.g., Ashraf et al., 2017; Shangarffam \& Poshti, 2011). In addition to these correlational studies, teachers' perceptions regarding implementing CT in different educational settings have been the subject of various studies (e.g., Marin \& Pava, 2017; Zhang et al., 2020). Some researchers have also explored the impacts of teaching the disposition to EFL teachers by implementing different language skills (e.g., Behdani \& Rashtchi, 2016, 2019; Sabah \& Rashtchi, 2016a, 2016b).

The present sequential mixed methods study consisted of two phases. The descriptive stage intended to verify whether there was a relationship between experienced and novice EFL teachers' CT and self-efficacy. Additionally, it aimed to examine whether there were differences between their CT and self-efficacy. In the next stage, an explanatory mixed methods study (Creswell, 2014) comprising a quantitative phase followed by a qualitative one was performed. The quantitative research had a static group comparison design (Best \& Kahn, 2006) examining the impact of thinking skills instruction on self-efficacy and CT. The qualitative section involved semi-structured interviews. The following research questions helped obtain the objectives.

RQ1: Is there a relationship between experienced EFL teachers' self-efficacy and CT?
RQ2: Is there a relationship between novice EFL teachers' self-efficacy and CT?

RQ3: Do novice and experienced teachers differ in the sense of self-efficacy?

RQ4: Do novice and experienced teachers differ in CT skills?

RQ5: Does teaching CT skills have any impact on teachers' self-efficacy and CT?

RQ6: How do participants perceive classroom instructions?

\section{METHODS}

\section{Participants}

One hundred and twenty Iranian EFL teachers selected in two different groups based on purposive sampling participated. One group comprised novice teachers with zero to five years of teaching, and the other group involved experienced teachers with more than ten years of experience. The researcher employed Palmer et al.'s (2005) criteria that regard five years of teaching experience to be the criterion in differentiating between novice and experienced teachers.

The participants had studied TEFL, English Translation, or English Literature and were either lecturing undergraduate students at different universities or were teaching in private language institutes in Tehran. Table 1 demonstrates their demographic information.

In the second phase, 20 novice male and female teachers who had participated in the first phase volunteered to take part in CT classes and formed the experimental group. Nineteen novice teachers who agreed to answer the CT and self-efficacy 
questionnaires for the second time after a formed the control group. Table 2 illustrates two-month interval without any treatment their demographic information.

Table 1

Participants' demographic information

\begin{tabular}{lcc}
\hline Gender & $\begin{array}{c}\text { Experienced Teachers } \\
>\mathbf{1 0}\end{array}$ & $\begin{array}{c}\text { Novice Teachers } \\
\mathbf{0 - 5} \text { Years }\end{array}$ \\
\hline Male & 25 & 28 \\
Female & 35 & 32 \\
Total & 60 & 60 \\
\hline Educational Degree & Ph.D. Holders & Ph.D. Students \\
& 25 & 20 \\
& M.A. & M.A. \\
& 30 & 15 \\
& B.A. & B.A. \\
Age Range & 5 & $22-32$ \\
\hline
\end{tabular}

Table 2

Participants' demographic information in experimental and control groups

\begin{tabular}{lcc}
\hline Gender & $\begin{array}{c}\text { Experimental Group } \\
\text { 0-5 Years }\end{array}$ & $\begin{array}{c}\text { Control Group } \\
\text { 0-5 Years }\end{array}$ \\
\hline Male & 5 & 7 \\
Female & 15 & 12 \\
Total & 20 & 19 \\
\hline Educational Degree & Ph.D. Students & Ph.D. Students \\
& 11 & 13 \\
& M.A. & M.A. \\
Age Range & 9 & $24-44$ \\
\hline
\end{tabular}

\section{Researcher}

The researcher instructed CT classes. As a personal interest, she has studied and practiced Philosophy for Children (P4C) since 2005. Translations of Thinking together
(Cam, 1998/2011), Thinking Stories (Cam, 1993/2007a, 1994/2007b, 1997/2007c) into Persian have helped her develop an understanding of CT and reflective teaching. She has also participated in some workshops 
and has run several workshops on $\mathrm{P} 4 \mathrm{C}$ in the Institute for Humanities and Cultural Studies in Tehran, Iran.

\section{Instruments}

The researcher used three tools to collect data. The first one was the California Critical Thinking Skills Test (CCTST), Form B. The test has been widely used to evaluate the respondents' CT skills in seven areas of analysis, interpretation, inference, evaluation, explanation, deduction, and induction. The test has 34 items in multiplechoice format and proposes different scenarios that require the respondents to demonstrate their reasoning and decisionmaking skills (Knox, 2013).

The second tool was Teachers' Sense of Efficacy Scale (TSES) developed by Tschannen-Moran and Hoy (2001). The scale has 24 items with reader answers from 1 (nothing) to 9 (a great deal) and examines three areas of instructional strategies, classroom management, and student engagement. The reliability indices of the questionnaire reported by the authors are $0.91,0.90$, and 0.87 for the three mentioned areas, respectively. The correlation of the TSES with previous scales of self-efficacy has guaranteed its construct validity (The survey is available at: https://wmpeople. wm.edu/site/page/mxtsch/researchtools).

The last instrument was a semistructured interview the researcher used to gather data regarding the participants' perceptions regarding the treatment and the extent to which it could affect their sense of self-efficacy. The researcher examined the clarity of the questions by asking two colleagues to explain what each meant to them (Appendix A).

\section{Materials}

For teaching CT skills, the researcher utilized The Critical Thinking Workbook by Global Digital Citizen Foundation (available at https://globaldigitalcitizen. org/resources). The book provides several activities that develop problem-solving, decision-making, argumentation, and reasoning, as the components of thinking skills (Marzano \& Pollock, 2001). The researcher also prepared some worksheets (printed off from the Critical Thinking workbook or designed by her) for classroom practice (Appendix B). The topics of the discussions were adopted from critical thinking resources (e.g., Lipman \& Sharp, 1980; Cam, 1997/2007c, 1998/2011).

\section{Procedure}

The First Phase. It took three months to gather the required data. Usually, one shortcoming of survey studies is that respondents do not answer the questionnaires willingly. This problem impelled the researcher first to contact individuals and explain the purpose of the study. If they agreed to participate, she sent the questionnaires via e-mail or referred to them in their workplace. No time limits were set for answering the surveys. However, the CCTST took about 45 minutes and TSES 10 to 15 minutes to answer. 
The Second Phase. Twenty novice teachers volunteered to participate in a critical thinking course run by the researcher. The classes continued for ten sessions, each session 100 minutes. The classroom arrangement was a U-shaped chair configuration so that the participants could see each other, and the teacher could see everyone during discussions. The teacher recorded the classroom discussions for further analysis.

The first session was devoted to lecturing on the background and definition of CT. The teacher addressed issues like what thought is, the difference between reflective thinking and undirected thinking, and the three types of critical, creative, and caring thinking. She also explained the importance of CT in educating people to become responsible citizens.

From sessions two to ten, each course followed two cycles. In the first cycle, the teacher started the class with a topic and a question on the board. Then she asked the participants to state their impression or answer the problem. Usually, five or six individuals offered their ideas, which the teacher wrote on the board with their names beside the comments. Writing the names helped the class address individuals when necessary. The teacher required the participants to reason for their choice of the best statement. This activity was the beginning of dialogic discussions or what is called Socratic dialog. The teacher challenged ideas, asked for reasons, insisted on considering others' perspectives, and invited the participants to draw conclusions and make generalizations. At the next stage, the teacher wrote on the board the concluding sentences expressed by every individual. Finally, each of the participants stated whether they agreed or disagreed with the conclusions. In the second cycle, which took about 20 minutes, the participants were engaged in doing worksheets. Table 3 shows the topics and activities done in each session.

Table 3

Classroom procedure for the critical thinking course

\begin{tabular}{lll}
\hline Sessions & Topics & Worksheets \\
\hline One & An introduction to critical thinking & - \\
Two & $\begin{array}{l}\text { Comparing fact and opinion; truth } \\
\text { and reality }\end{array}$ & $\begin{array}{l}\text { Writing statements about fact and } \\
\text { opinion }\end{array}$ \\
\multirow{2}{*}{ Three } & Fairness. Are you a fair person? & $\begin{array}{l}\text { Scenarios on cases of making decisions } \\
\end{array}$ \\
& Can you give examples of instances & in tense situations \\
& that you think you have/have & \\
& not been fair? Providing some & \\
& scenarios for discussion & \\
\hline
\end{tabular}


Table 3 (Continued)

\begin{tabular}{lll}
\hline Sessions & Topics & Worksheets \\
\hline Four & $\begin{array}{l}\text { Rules, regulations, and self- } \\
\text { regulation. Should we always obey } \\
\text { the rules? What will be the outcomes } \\
\text { of following/not obeying the rules? }\end{array}$ & $\begin{array}{l}\text { Scenarios on incidents that people } \\
\text { may or may not obey the rules }\end{array}$ \\
Five & $\begin{array}{l}\text { Discussing "what would happen if } \\
\text { you had one day to live? }\end{array}$ & $\begin{array}{l}\text { Scenarios on instances of what would } \\
\text { happen if... }\end{array}$ \\
Six & $\begin{array}{l}\text { Time. How would it have been like if } \\
\text { we had not had the concept of time? }\end{array}$ & $\begin{array}{l}\text { Write ten things which can be done / } \\
\text { cannot be done in a time limit. }\end{array}$ \\
Seven & $\begin{array}{l}\text { Decision making. Do teachers think } \\
\text { about how their decisions may affect } \\
\text { students' lives? }\end{array}$ & $\begin{array}{l}\text { Write examples of instances in which } \\
\text { a teacher is allowed/not allowed to } \\
\text { violate the rules of teaching. }\end{array}$ \\
Eight & $\begin{array}{l}\text { Kindness. To what extent can we be } \\
\text { kind to people? And to our students? }\end{array}$ & $\begin{array}{l}\text { The participants were provided with } \\
\text { some scenarios on challenging issues } \\
\text { to decide whether to be kind or not }\end{array}$ \\
& $\begin{array}{l}\text { Devotion. How can we show our } \\
\text { dedication to our country, job, family, } \\
\text { Nine }\end{array}$ & $\begin{array}{l}\text { Write an imaginary dialogue with } \\
\text { someone who is not devoted to his/ } \\
\text { her job. }\end{array}$ \\
& $\begin{array}{l}\text { Responsibility. What responsibilities } \\
\text { do we have in our life/job? }\end{array}$ & $\begin{array}{l}\text { Write ten statements that show you } \\
\text { are a responsible person. }\end{array}$ \\
\hline
\end{tabular}

During discussions, the participants were quite active and seemed to appreciate the procedure. Their improvement in becoming tolerant, listening to others before starting to talk, and trying to look for reasons to convince others was conspicuous. One significant characteristic that developed gradually was that when the learners were asked questions or their viewpoints were challenged, they avoided abrupt reactions. They paused for a few seconds to give themselves some time to think and started to talk expressively. This feature was vital as it was a sign of thinking, evaluating, and finding reasons to defend their position before passing judgment. The following are excerpts from the conversations in sessions three and ten among participants A (PA), B (PB), C (PC), and the teacher (T).

\section{Excerpt One, Session Three.}

PA: What does fairness have to do with teaching? ... we are mixing things up. I don't find any association between being a teacher and fairness.

T: Don't you think, as teachers, we have some responsibilities?

$P A$ : Is fairness a responsibility?

PC: It is not. We must teach and follow the rules of the institute, ... I don't want trouble. T: Don't you think that by being unfair to our students, we are giving them a bad feeling no matter how good we are teaching? 
PA: It does not concern me. It is difficult to take charge of these things. I must develop lesson plans ...not think about marginal things...

PB: I was treated like that ......

T: When you were a student?

PB: Yes. Unfair, and I felt miserable.

$T$ to PA: Can you point to a teachers' responsibilities? I am going to write them down on the board.

\section{Excerpt Two, Session Ten.}

PA: I think I have some implicit responsibilities. I believe we can help our students behave appropriately; it needs patience.

PC: Having good relations with parents of trouble makers [students].

PA: Ensuring that everyone is learning...

T: How?

PA: By selecting different teaching methods. $P B$ : Checking if all students are learning... $P C$ : Looking at all students with one eye... PA: Do something encouraging in class.

\section{Post-test}

In the eleventh session, 20 participants in the experimental group and 19 members in the control group sat for the CCTST and TSES.

\section{Interview}

Seven teachers from the experimental group agreed to participate in the interviews. The first two questions served as warm-up questions to build an emotional relationship between the researcher and the respondents. Questions three to seven were the primary concern of the study. They explored the extent to which the treatment could have caused changes in the participants' CT and whether such changes could be related to self-efficacy. With participants' consent, the conversations were recorded. Each interview session took about 30 minutes.

\section{RESULTS}

\section{First Phase}

Pearson's $r$ was used to answer the first research question. As Table 4 shows, there was a positive relationship between self-efficacy (SE) and CT of experienced teachers. The strength of the relationship, as indicated by Cohen ( $r=.10$ to .29 small, $\mathrm{r}=.30$ to .49 medium, $\mathrm{r}=.50$ to 1.0 large, 1988, pp. 79-81), is large $(\mathrm{r}=.70>.50)$. The coefficient of determination, helped the researcher discovered how much variance the two variables shared and was obtained by squaring $r$ value $(r=.70)$. The result shows a 49 percent overlap between CT and self-efficacy. In other words, critical thinking helps explain $49 \%$ of the variance in respondents' scores on the selfefficacy questionnaire. Therefore, since the coefficient exceeds the significance level (.05), it can be stated that there is a strong, positive correlation between the two variables, $r=.70, n=60, p \leq 0.01$, with high levels of CT related to high levels of self-efficacy.

The same computations were used to address the second research question. Table 5 shows a positive relationship between self-efficacy and CT of novice teachers. The strength of the relationship is large $(r=.585>.50)$. The coefficient of 
determination shows a 34\% overlap between efficacy and CT of novice teachers, $r=.5850$, the two variables. In other words, there is a $n=60, p \leq .01$.

strong, positive correlation between self-

Table 4

Correlation between experienced teachers'self-efficacy and CT

\begin{tabular}{lccc}
\hline & SE & CT \\
\hline SE & Pearson Correlation & 1.000 & .702 \\
& Sig. (2-tailed) & & .000 \\
& N & 60 & 60 \\
CT & Pearson Correlation & .702 & 1.000 \\
& Sig. (2-tailed) & .000 & 60 \\
& N & 60 & \\
\hline
\end{tabular}

*Correlation significant at .01 level

Table 5

Correlation between novice teachers'self-efficacy and CT

\begin{tabular}{lccc}
\hline & & SE & CT \\
\hline SE & Pearson Correlation & 1.000 & .585 \\
& Sig. (2-tailed) & & .000 \\
$\mathrm{~N}$ & 60 & \\
$\mathrm{CT}$ & Pearson Correlation & .585 & 1.000 \\
& Sig. (2-tailed) & .000 & 60 \\
& $\mathrm{~N}$ & 60 & \\
\hline
\end{tabular}

*Correlation significant at .01 level

The next step was to examine whether the two groups' correlation values were significantly different using the online calculator available at http://vassarstats. net/rdiff.html (Pallant, 2016). In the online calculator, the two correlation values (i.e., .70 and .60) and the number of participants in each group were entered. The result of the procedure (Table 6) shows that $\mathrm{z}$ value was equal to .93, and the p-value (two-tailed) is .35. Since the p-value is larger than .05, the result is not statistically significant. Thus, it can be inferred that experienced and novice teachers' correlation coefficient values were not statistically significant, although a higher correlation was observed for experienced teachers $(r=.70)$. It can be concluded that the relation between self- 
efficacy and CT is independent of years of experience.

The researcher compared the groups' means for each trait to answer the third and fourth research questions. Table 7 shows the descriptive statistics on self-efficacy and CT. The skewness ratios (obtained from dividing statistic by standard error) were 2.19 and 0.92 for the experienced teachers' group and 1.03 and 2.03 for the novice teachers' group on the two traits. The ratios beyond \pm 1.96 indicate that the distribution of the scores on CT and self-efficacy scales were not normal, and parametric tests for comparing the mean scores of the groups could not be utilized.
Thus, the non-parametric Man-Whitney U test was employed for comparing the means.

As Table 8 reveals, there was no statistically significant difference between the two groups regarding self-efficacy $U=$ $1657, p=0.453$, and CT $U=1762, p=0.842$. The $p$-values (larger than 0.05 ) indicated that the two groups did not differ in their levels of CT and self-efficacy. In sum, the statistical analyses revealed a relationship between self-efficacy and CT, and there were no statistically significant differences between experienced and novice teachers regarding the two traits.

Table 6

Difference between groups' correlations using an online calculator

\begin{tabular}{|c|c|c|c|c|}
\hline \multirow[t]{2}{*}{ Teachers } & \multirow[t]{2}{*}{$\mathrm{r}$} & \multirow[t]{2}{*}{$\mathrm{n}$} & Obtained z value & p-value \\
\hline & & & \multicolumn{2}{|c|}{ (two-tailed) } \\
\hline Experienced & .70 & 60 & .93 & .35 \\
\hline Novice & .60 & 60 & & \\
\hline
\end{tabular}

Table 7

Groups' descriptive statistics for self-efficacy and critical thinking

\begin{tabular}{|c|c|c|c|c|c|c|c|}
\hline & \multirow[b]{2}{*}{$\mathrm{N}$} & \multirow[b]{2}{*}{ Min. } & \multirow[b]{2}{*}{ Max. } & \multirow[b]{2}{*}{ Mean } & \multirow[b]{2}{*}{ SD } & \multicolumn{2}{|c|}{ Skewness } \\
\hline & & & & & & Statistic & $\begin{array}{l}\text { Std. } \\
\text { Error }\end{array}$ \\
\hline \multicolumn{8}{|l|}{ SE } \\
\hline Experienced & 60 & 111.00 & 194.00 & 160.11 & 28.122 & -0.678 & 0.309 \\
\hline Novice & 60 & 108.00 & 210.00 & 157.83 & 30.313 & -0.320 & 0.309 \\
\hline \multicolumn{8}{|l|}{$\mathrm{CT}$} \\
\hline Experienced & 60 & 16.00 & 28.00 & 21.36 & 3.019 & 0.285 & 0.309 \\
\hline Novice & 60 & 16.00 & 29.00 & 21.40 & 3.026 & 0.620 & 0.309 \\
\hline
\end{tabular}


Table 8

Results of Mann-Whitney U on self-efficacy and critical thinking

\begin{tabular}{lc}
\hline Mann-Whitney U & Results \\
\hline Mann-Whitney U - Self-efficacy & 1657.500 \\
Wilcoxon W & 3487.500 \\
Z & -0.750 \\
Asymp. Sig. (2-tailed) & 0.453 \\
\hline Mann-Whitney U- Critical Thinking & 1762.500 \\
Wilcoxon W & 3592.500 \\
Z & -0.199 \\
Asymp. Sig. (2-tailed) & 0.842 \\
\hline
\end{tabular}

\section{Second Phase}

Quantitative Analysis. The results of the participants' scores on the two questionnaires were extracted from the first phase and compared via independent samples t-test to examine whether the experimental $(n=20)$ and control $(n=19)$ groups differed in their mean scores obtained from TSES and CCTST before the treatment. Table 9 shows the descriptive statistics. The skewness ratios had to be computed to ensure the use of parametric tests for comparing the groups' means on CT and self-efficacy. The skewness ratios of the experimental group's self-efficacy $(\mathrm{M}=154, \mathrm{SD}=31.36)$ and $\mathrm{CT}(\mathrm{M}=21, \mathrm{SD}=2.70)$ were 0.3 and 0.22 . The skewness ratios of the control group's self-efficacy $(\mathrm{M}=149, \mathrm{SD}=31.23)$ and $\mathrm{CT}(\mathrm{M}=21, \mathrm{SD}=3.5)$ were 1.84 and 1.43 . Since all ratios fell between \pm 1.96 , it could be concluded that the distributions of the groups' scores on both scales were normal to perform parametric tests.

Table 9

Descriptive statistics on self-efficacy and critical thinking before treatment

\begin{tabular}{llllllll}
\hline & N & Min. & Max. & Mean & SD & \multicolumn{2}{c}{ Skewness } \\
& statistic & statistic & statistic & statistic & statistic & Statistic & Std. Error \\
\hline SE Experimental & 20 & 108.00 & 210.00 & 154.30 & 31.367 & -0.160 & 0.512 \\
SE Control & 19 & 108.00 & 210.00 & 149.84 & 31.232 & 0.116 & 0.524 \\
CT Experimental & 20 & 18.00 & 27.00 & 20.90 & 2.693 & 0.944 & 0.512 \\
CT Control & 19 & 16.00 & 29.00 & 20.94 & 3.503 & 0.751 & 0.524 \\
\hline
\end{tabular}


Table 10 illustrates the results of the independent samples t-test before the treatment. As shown, there were no statistically significant differences between the self-efficacy $\mathrm{t}(37)=.445, \mathrm{p}=.66$, and CT $\mathrm{t}(37)=.047, \mathrm{p}=.96$ of the groups ( $\mathrm{p}$-values larger than .05 indicate no statistically significant differences). This test could ensure the researcher that any changes in the experimental group would be due to the treatment.

For answering the fifth research question, Multivariate analysis of variance was conducted to investigate whether there was a statistically significant difference between the two dependent variables of the experimental and control groups (i.e., selfefficacy and CT). One condition for running
MANOVA is that the dependent variables should be related (Pallant, 2016). The results obtained from the first phase of the study (i.e., running Pearson's $r$ to examine the correlation between self-efficacy and CT of experienced and novice teachers) indicated a strong relationship between self-efficacy and critical thinking $(r=.70$ for the experienced and $r=.585$ for the novice teachers). Therefore, the use of a MANOVA was appropriate. The test investigated whether there was a statistically significant difference between the two dependent variables of the groups after the treatment. Table 11 shows the descriptive statistics.

The preliminary assumption was performed to examine for normality and homogeneity of variance-covariance

Table 10

Independent samples t-test for self-efficacy and critical thinking, pretest

\begin{tabular}{|c|c|c|c|c|c|c|c|c|c|}
\hline & \multicolumn{5}{|c|}{$\begin{array}{l}\text { Leven's test for } \\
\text { Equality of Variances }\end{array}$} & \multicolumn{2}{|c|}{$\begin{array}{l}\text { t-test for equality } \\
\text { of means }\end{array}$} & \multicolumn{2}{|c|}{$\begin{array}{l}95 \% \text { Confidence } \\
\text { Interval of } \\
\text { Difference }\end{array}$} \\
\hline & $\mathrm{F}$ & Sig. & $\mathrm{t}$ & $\mathrm{df}$ & $\begin{array}{l}\text { Sig. } \\
\text { 2tailed }\end{array}$ & $\begin{array}{l}\text { Mean } \\
\text { Dif. }\end{array}$ & $\begin{array}{l}\text { Std. } \\
\text { Error } \\
\text { Dif. }\end{array}$ & Lower & Upper \\
\hline $\begin{array}{l}\text { SE } \\
\text { Equal } \\
\text { variances } \\
\text { assumed }\end{array}$ & 0.006 & 0.938 & 0.445 & 37 & 0.659 & 4.457 & 10.027 & -15.860 & 24.776 \\
\hline $\begin{array}{l}\text { CT } \\
\text { Equal } \\
\text { variances } \\
\text { assumed }\end{array}$ & 0.298 & 1.14 & 0.047 & 37 & 0.962 & -0.0473 & 0.9975 & -2.06 & 1.97 \\
\hline
\end{tabular}


matrices. As Table 12 shows, since the last row in the table), the assumption of $\mathrm{p}$-value $=.119$ was larger than 0.05 (the normality was not violated ( $\mathrm{p}>.05)$.

Table 11

Descriptive statistics of the groups on the post-tests

\begin{tabular}{lllll}
\hline & Groups & Mean & SD & N \\
\hline SE & Experimental & 177.6000 & 24.83715 & 20 \\
& Control & 150.4737 & 30.85156 & 19 \\
& Total & 164.3846 & 30.78928 & 39 \\
\hline CT & Experimental & 27.8500 & 2.03328 & 20 \\
& Control & 21.1053 & 3.03488 & 19 \\
& Total & 24.5641 & 4.25376 & 39 \\
\hline
\end{tabular}

Table 12

Box's test of equality of covariance matrices

\begin{tabular}{ll}
\hline Statistic & Result \\
\hline Box's M & 6.210 \\
F & 1.949 \\
df1 & 3 \\
df2 & 271286.853 \\
Sig. & .119 \\
\hline
\end{tabular}

As Table 13 shows, the $p$-values $(p=.261$ $\& p=.074$ ) were larger than 0.05 ; thus, the assumption of the homogeneity of variances ( $>$ >.05) was met for both constructs.
As illustrated in Table 14, there was a statistically significant difference between the experimental and control groups on the dependent variables, $\mathrm{F}(2,36)=34.06$, $\mathrm{p}<.001$; Wilks' Lambda $=0.37$. Partial eta squared effect size that shows the proportion of the dependent variable explained by the independent variable was 0.654 , indicating a large effect size $(0.01$ or $1 \%$ Small, 0.06 or $6 \%$ Medium., 0.138 or $13.8 \%$ Large; Cohen, 1988). Therefore, 65 percent of the variation in the dependent variables was due to the treatment the participants received.

Table 13

Levene's test of equality of error variances

\begin{tabular}{lccccc}
\hline & & & & \\
& & Levene & & \\
& Statistic & df1 & df2 & Sig. \\
\hline SE & Based on Mean & 1.301 & 1 & 37 & .261 \\
CT & Based on Mean & 3.381 & 1 & 37 & .074 \\
\hline
\end{tabular}


Multivariate tests

\begin{tabular}{|c|c|c|c|c|c|c|c|}
\hline \multirow{2}{*}{ Effect } & & \multicolumn{5}{|c|}{ Hypothesis } & \multirow{2}{*}{$\begin{array}{l}\text { Partial Eta } \\
\text { Squared }\end{array}$} \\
\hline & & Value & $\mathrm{F}$ & df & Error df & Sig. & \\
\hline \multirow[t]{4}{*}{ Intercept } & $\begin{array}{l}\text { Pillai's } \\
\text { Trace }\end{array}$ & 0.990 & 1733.128 & 2 & 36 & .000 & .990 \\
\hline & $\begin{array}{l}\text { Wilks' } \\
\text { Lambda }\end{array}$ & 0.010 & 1733.128 & 2 & 36 & .000 & .990 \\
\hline & $\begin{array}{l}\text { Hotelling's } \\
\text { Trace }\end{array}$ & 96.285 & 1733.128 & 2 & 36 & .000 & .990 \\
\hline & $\begin{array}{l}\text { Roy's } \\
\text { Largest } \\
\text { Root }\end{array}$ & 96.285 & 1733.128 & 2 & 36 & .000 & .990 \\
\hline \multirow[t]{4}{*}{ Groups } & $\begin{array}{l}\text { Pillai's } \\
\text { Trace }\end{array}$ & 0.654 & 34.059 & 2 & 36 & .000 & .654 \\
\hline & $\begin{array}{l}\text { Wilks' } \\
\text { Lambda }\end{array}$ & 0.346 & 34.059 & 2 & 36 & .000 & .654 \\
\hline & $\begin{array}{l}\text { Hotelling's } \\
\text { Trace }\end{array}$ & 1.892 & 34.059 & 2 & 36 & .000 & .654 \\
\hline & $\begin{array}{l}\text { Roy's } \\
\text { Largest } \\
\text { Root }\end{array}$ & 1.892 & 34.059 & 2 & 36 & .000 & .654 \\
\hline
\end{tabular}

Qualitative Analysis. Question 3 probed the respondents' perceptions regarding the instruction. The answers showed that they were optimistic and appreciated the activities. However, they all asserted that before attending the classes, they did not know much about CT or its implementation:

"It was interesting to learn about critical thinking, I had heard about it before but did not know what exactly it was."

"I learned how critical thinking is practiced and what issues it covers."
Regarding question 4, the respondents acknowledged some changes in their viewpoints. The crucial issue was that they had never thought about the concepts discussed during the course. They believed that the classes kindled a new way of looking at things and made them aware of the outcome of their actions. The participants confirmed that cognitive involvement and concentration on a subject could enable them to follow a line of thinking and avoid moving from one issue to another without any definite conclusion achieved. They had found out how difficult decision-making was and how one's decisions might have 
different impacts. The following excerpts are clarifying:

"I learned to look at things from different perspectives. For making the best decision, I should think about what happens if I were in another person's position."

"I had not thought deeply about decision-making and how it affects others. Now, I am aware [decisions] have outcomes...for example, failing a student or correcting papers."

"The highlights of the discussions was fairness. I had not thought about it before. I'll try to be fair to everyone and to re-evaluate my actions."

"I learned to think... I had never engaged in deep thinking before...I believe."

"I realized that there is not a single solution. Things are too complex; solving them needs deep thinking with others."

"I learned to give a second thought to my decisions before taking action."

In sum, the answers led the researcher to infer that the course was successful in introducing CT. It showed the difference between the perspectives of a critical thinker and others. Problem-solving and decisionmaking activities were useful in activating the teachers' attention to the actions they should take in challenging situations.

The answers to question 5 were fascinating. The interviewees had decided to formulate more profound questions to invite students to practice thinking:

"I will try to ask more open-ended questions and be less instructive and give more class time to students."

"I will try to prepare some inferential questions from the English lessons."

They would also try to relate the themes of the English lessons to CT-related issues:

"I will select topics to stimulate thinking in conversation classes. In writing classes, I will choose topics to activate thinking skills."

The respondents also mentioned they would consider alternative classroom activities:

"I will go for group activities to help learners work together and promote their patience for others' viewpoints."

"I will use more questioning and answering to let students give and receive feedback from classmates."

Question 6 stimulated complaints regarding troublemaking students. However, the respondents asserted that the classes helped them think about ways to deal with challenging situations, be more patient, and look for ways to calm down learners instead of disregarding them:

"I think problems need to be solved; I have to re-try to learn how to deal with upsetting situations."

The teachers believed that the course encouraged thinking about their classroom practices and self-evaluation. Additionally, 
looking for reasons would help them in establishing fruitful relations with students, administrators, and parents. They believed that the type of classroom management used in the course exemplified how to start dialogs, activate learners, and create an atmosphere to stimulate interaction. The general belief was that classroom management was related to success in establishing a good rapport with students.

Responses to the last question were affirmative. The interviewees believed that although they needed more practice, the classes were a new experience and had helped them develop a positive attitude toward their careers. They maintained that learning is a process of thinking, and teachers should help learners in the process:

"I have to be a more energetic teacher."

In sum, respondents verified that the classes contributed to the realization of how to involve in deep thinking. The interviewees stated that the course gave them self-confidence as they noticed their improvement in thinking activities. They asserted that similar classes in the future would be fruitful.

\section{DISCUSSION}

While the results of the first phase were in line with previous studies (e.g., Kozikoğlu, 2019; Shangarffam \& Poshti, 2011), it revealed that years of experience is not an indicator of the degree of self-efficacy and critical thinking skills. Although this finding cannot address the questions of causality, the correlations between "good thinking"
(Lipman, 2003, p. 36) and positive emotions toward the teaching profession can deepen our understanding of teacher education domain. The relationship between the two influential characteristics can lead educators to conclude that fostering thinking skills can motivate teachers and promote their selfconfidence, as stated by the interviewees. It can have a role in the teachers' well-being and help them avoid "negative emotionssuch as anxiety, sadness, anger, and despair" (Fredrickson, 2001, p. 218). Fostering EFL teachers' critical thinking can enhance their attention and understanding and contribute to their classroom actions. It can also improve their interactions with students, parents, and administrators, as the participants' assertions in the interview sessions clarified. This finding is consistent with Johnson's (1999) explanation of reflective teaching. Likewise, the argument finds support from the broaden-and-build theory of positive emotions, which argues that by "building people's personal and social resources, positive emotions transform people for the better, giving them better lives in the future" (Fredrickson, 2001, p. 224). The author of the present research goes further to postulate that critical thinking practices pave the way for the construction of positive emotions that EFL teachers need to develop their teaching behavior. This change can affect their views of themselves and give them the self-confidence to reason and analyze issues when encountering challenging situations. The results obtained from the second phase of the study constitute a complement to this assumption. 
The relatively low scores of the respondents on CCTS and TSES in the first stage justified the implementation of the second phase. The positive impact of instruction on self-efficacy and critical thinking showed that teaching thinking skills could support teachers in changing their viewpoints regarding themselves and gaining self-confidence vis-à-vis taking charge of their environment. The researcher assumes that instruction activated the participants' cognitive skills toward thinking and could "increase the probability of a desirable outcome" (Halpern, 1999, p. 70). Classroom practices provoked teachers' consciousness to view the process of teaching from a different perspective. Thus, it can be postulated that the instructions could affect teacher cognition; that is, "the unobservable cognitive dimension of teaching-what teachers know, believe, and think" (Borg, 2003, p. 81). The discussion and activities helped the participants practice purposeful thinking, or as Paul (1995) mentioned, think about thinking.

Moreover, as stated by the interviewees, tasks such as problem-solving, decisionmaking, reasoning, and argumentation are appropriate practices for improving thinking ability. These tasks give individuals insight into different issues, shape their perspectives, help them defend their viewpoints, and finally provoke their thinking. The findings underline the value of implementing discussions as a strategy that can cultivate thinking skills (Freely \& Steinberg, 2014; Rashtchi \& Sadraeimanesh, 2011). As Paul et al. (1995) argued, individuals should be provided with opportunities "to puzzle their way through to knowledge and explored its justification, as part of the process of learning" (p. 300).

The results find support from researchers who maintain that adult learners do not naturally use critical thinking skills, but these complex abilities develop over time (Kurfiss, 1983; Paul, 1993) and can change the quality of their thinking (Rashtchi, 2007; Schafersman, 1991). It seems that practicing higher-order thinking skills can provide an appropriate way to develop what teachers need for success in encountering students, parents, and administrators as they can be involved in an ongoing process of self-evaluation and evaluation of others. Engaging in reasoning skills can affect how teachers conceive themselves and can help them demonstrate their expertise in educational settings.

One issue to consider is that teacher education programs mainly focus on technological improvement, pedagogical knowledge, and conceptual understanding of the content (Koehler \& Mishra, 2009). However, incorporating knowledge of thinking and reasoning skills may accelerate teacher development (Rashtchi \& Khoshnevisan, 2019) and help teachers in schooling their students. Pre- and in-service teacher training courses are suggested to include such activities in their curriculum to encourage teachers to think about past experiences that can lead to creating reflective teachers (Peacock, 2009). Many studies have indicated that teachers do not precisely know what critical thinking is 
(Marin \& Pava, 2017; Zhang et al., 2020). The participants' answers to the third interview question, in line with the previous studies, verify their lack of knowledge about critical thinking. Thus, incorporating such understanding into teacher training courses seems beneficial for cultivating thinking skills and in the long-run to the betterment of societies.

As inferred from the interviews, the treatment was useful in stimulating teachers' thinking skills and drawing their attention to subjects that are decisive in teaching but are considered as common understanding, such as fairness, decision-making, and selfassessment. As the respondents asserted, the classes could encourage them to consider evaluating themselves and their teaching habits. They believed that they should look for different teaching methods and strategies to meet all students' learning styles and preferences. This finding coincides with Bandura's (1997) definition that teachers' decisions to achieve goals and their ability to take actions to accomplish them signify their self-efficacy. Bandura (1986) believed that reflection was the most prominent characteristic of human beings enabling them to evaluate themselves and their thoughts. Consistent with this idea is the concept of reflective teaching, which has been the focus of researchers who assign a dynamic role to teachers as curriculum developers, professional decision-makers, and problem solvers (e.g., Dewey, 1933; Hillier, 2005). Thus, the primary concern of teacher educators should be fostering such characteristics by employing appropriate training courses and developing necessary materials.

The treatment, as stated by the respondents, had encouraged asking more profound questions in EFL classes and seizing the opportunity to trigger students' thinking skills. This finding shows the teachers' realization of the importance of critical thinking. Accordingly, it is in line with the concept of reflective teaching, which defines reflectivity as creating situations to encourage curiosity (Dewey, 1933).

Another highlight extracted from the interviews was that critical thinking classes portrayed an active classroom environment with utmost engagement in the learning process. This finding underscores the benefits of activity-based courses, which allows teachers to practice thinking instead of listening to lectures about critical thinking. The classes could invite the participants to self-reflection, the result of which would be reconsidering teaching techniques, strategies, and behaviors that relate critical thinking to self-efficacy in the three areas of instructional strategies, classroom management, and student engagement (Tschannen-Moran \& Hoy, 2001).

Correlational studies would be of little use in explaining teacher development unless they ignite discussions for coming up with practical programs for promoting teachers' capabilities, such as self-efficacy and critical thinking. Teacher education requires interventional studies that suggest how to affect teacher characteristics to become agents who can leave their impacts 
on educational settings. Without designing appropriate programs for training teachers to be reflective, discussions on the merits of reflective teaching would remain at theoretical levels. Teachers should practice analyzing, questioning, evaluating, selfevaluating, and decision-making as critical thinking components in pre- and in-service programs.

\section{CONCLUSION}

Teachers play a primary role in education since the changes in teachers' characteristics will improve students' learning. This study showed the decisive role of instruction on the development of teachers' thinking skills and self-efficacy after the relationship between the two dispositions was verified in the first phase of the study. The findings lead the researcher to suggest incorporating critical thinking instruction in teacher training courses. It is time to move from theorizing to taking practical steps for upgrading education by cultivating critical thinking among EFL teachers. One component of teachers' knowledge base should include teachers' performances in higher-order thinking skills, fostered by thinking practices. It would be good to look at critical thinking as a line of pedagogy and expect administrators, policymakers, and curriculum developers to work for its establishment in all areas of teacher education.

Further studies should focus on the role of critical thinking on other teacher characteristics like motivation and burnout. One limitation of the study was that teachers volunteered to take part in its different phases. Therefore, one possibility is that the participants had higher motivation than typical teachers. Another limitation was the lack of a follow-up study to examine the extent to which critical thinking the instructions have lasting impacts on teachers' thinking and performance.

\section{ACKNOWLEDGEMENT}

I am thankful to my friend, Dr. Farzaneh Shahrtash, who introduced to me the concept of critical thinking some twenty years ago. She encouraged me to learn and work in the domain. Her encouragement has changed my view of teaching.

\section{REFERENCES}

Allinder, R. (1994). The relationship between efficacy and the instructional practices of special education teachers and consultants. Teacher Education and Special Education, 17, 86-95. https://doi.org/10.1177/088840649401700203

Ashraf, H., Garmabi, H., \& Fayendari, M. B. (2017). Do critical thinking skills lead to success in language teaching? A case of Iranian EFL teachers based on their gender and degree of education. The Journal of English Language Pedagogy and Practice, 10(20), 17-28.

Bandura, A. (1977). Self-efficacy: Toward a unifying theory of behavioral change. Psychological Review, 84, 191-215. https://doi. org/10.1037/0033-295x.84.2.191

Bandura, A. (1986). Social foundations of thought and action: A social-cognitive theory. Prentice-Hall.

Bandura, A. (1995). Self-efficacy in changing societies. Cambridge University Press. 
Bandura, A. (1997). Self-efficacy: The exercise of control. Freeman.

Behdani, R. S., \& Rashtchi, M. (2016). Assessing critical thinking ability via the writing process: Developing and implementing a rating scale. Iranian. Journal of English for Academic Purposes, 5(2), 97-115.

Behdani, R. S., \& Rashtchi, M. (2019). Process writing and enhancement of critical thinking ability: Is writing a vehicle or an ingredient of critical thinking? Iranian Journal of Applied Language Studies, 11(1), 181-200.

Best, J. W., \& Kahn, J. (2006). Research in education (10th ed.). Pearson.

Borg, S. (2003). Teacher cognition in language teaching: A review of research on what language teachers think, know, believe, and do. Language Teaching. 36, 81-109. https://doi.org/10.1017/ s0261444803001903

Bouffard-Bouchard, T. (1990). Influence of selfefficacy on performance in a cognitive task. The Journal of Social Psychology, 130(3), 353-363. https://doi.org/10.1080/00224545.1990.9924591

Cam, P. (2007a). Thinking stories: Philosophical inquiry for children: Vol.1 (F. Shahrtash \& M. Rashtchi, Trans.). Hale \& Ironmonger. (Original work published in 1993).

Cam, P. (2007b). Thinking stories: Philosophical inquiry for children: Vol.2 (M. Rashtchi \& F. Shahrtash, Trans.). Hale \& Ironmonger. (Original work published in 1994).

Cam, P. (2007c). Thinking stories: Philosophical inquiry for children: Vol.3 (F. Shahrtash, N. Ebrahimi, \& M. Rashtchi, Trans.). Hale \& Ironmonger. (Original work published in 1997).

Cam, P. (2011). Thinking together: Philosophical inquiry for the classroom (M. Rashtchi \& F. Shahrtash, Trans.). Hale \& Ironmonger. (Original work published in 1998).
Chacón, C. (2005). Teachers' perceived efficacy among English as a foreign language teacher in middle schools in Venezuela. Teaching and Teacher Education, 21(3), 257-272. https://doi. org/10.1016/j.tate.2005.01.001

Cohen, J. W. (1988). Statistical power analysis for the behavioral sciences (2nd ed.). Lawrence Erlbaum.

Creswell, J. W. (2014). Research design. Sage.

Dewey, J. (1933). How we think. Heath.

Facione, P. (1990). Critical thinking: A statement of expert consensus for purposes of educational assessment and instruction. The California Academic Press.

Fisher, A. (2001). Critical thinking an introduction. Cambridge University Press.

Fredrickson, B. L. (2001). The role of positive emotions in positive psychology: The broadenand-build theory of positive emotions. American Psychologist, 56(3), 218-226. https://doi. org/10.1037/0003-066x.56.3.218

Freely, A. J., \& Steinberg, D. L. (2014). Argumentation and debate: Critical thinking for reasoned decision making. Cengage Learning.

Guskey, T. R. (1988). Teacher efficacy, self-concept, and attitudes toward the implementation of instructional innovation. Teaching and Teacher Education, 4(1), 63-69. https://doi. org/10.1016/0742-051x(88)90025-x

Halpern, D. F. (1999). Teaching for critical thinking: Helping college students develop the skills and dispositions of a critical thinker. New Directions for Teaching and Learning, 80, 69-74. https://doi. org/10.1002/t1.8005

Hillier, Y. (2005). Reflective teaching in further and adult education. A\&C Black.

Johnson, K. E. (1999). Understanding language teaching: Reasoning in action. Heinle \& Heinle. 
Knox, D. K. (2013). The California critical thinking skills test. Clemson Thinks. http://www.clemson. edu/academics/programs/thinks2/documents/ scholars/summer_2013/knox_cctst.pdf

Koehler, M. J., \& Mishra, P. (2009). What is technological pedagogical content knowledge? Contemporary Issues in Technology and Teacher Education, 9(1), 60-70.

Kozikoğlu, I. (2019). Investigating critical thinking in prospective teachers: Metacognitive skills, problem solving skills and academic selfefficacy. Journal of Social Studies Education Research, 10(2), 111-130.

Kumaravadivelu, B. (2003). Beyond methods: Macrostrategies for language teaching. Yale University Press.

Kurfiss, J. (1983). Intellectual, psychosocial, and moral development in college: Four major theories. Council for Independent Colleges. https://eric.ed.gov/?id=ED295534

Lipman, M. (1984). The cultivation of reasoning through philosophy. Educational Leadership, $42(2), 51-56$.

Lipman, M. (2003). Thinking in education (2nd ed.). Cambridge University Press.

Lipman, M., \& Sharp, A. M. (1980). Writing: How and why. Institute for the Advancement of Philosophy for Children.

Marashi, H., \& Azizi-Nassab, F. (2018). EFL teachers' language proficiency, classroom management, and self-efficacy. International Journal of Foreign Language Teaching \& Research, 6(22), 89-102.

Marin, M. A., \& Pava, L. (2017). Conceptions of critical thinking from university EFL teachers. English Language Teaching, 10(7), 78-88. https://doi.org/10.5539/elt.v10n7p78

Marzano, R. J., \& Pollock, J. E. (2001). Standardsbased thinking and reasoning skills. In A. L.
Costa (Ed.), Developing minds, a resource book for teaching thinking (pp. 29-35). Association for Supervision and Curriculum Development.

Pajares, F. (1996). Self-efficacy beliefs in academic settings. Review of Educational Research, 66(4), 543-578. https://doi. org/10.3102/00346543066004543

Pallant, J. (2016). SPSS survival manual (6th ed.). Open University Press.

Palmer, D. J., Stough, L. M., Burdenski, T. K., \& Gonzales, M. (2005). Identifying teacher expertise: An examination of researchers' decision making. Educational Psychologist, 40(1), 13-25. https://doi.org/10.1207/ s15326985ep4001_2

Paul, R. W. (1993). Critical thinking. Foundation for Critical Thinking.

Paul, R. W. (1995). The logic of creative and critical thinking. The Foundation for Critical Thinking.

Paul, R. W., Binker, A. J. A., Martin, D., \& Adamson, K. (1995). Critical thinking handbook: High school. Center for Critical thinking and Moral Critique.

Peacock, M. (2009). The evaluation of foreignlanguage-teacher education programmes. Language Teaching Research, 13(3), 259-278. https://doi.org/10.1177/1362168809104698

Pintrich, R., \& De Groot, E. (1990). Motivational and self-regulated learning components of classroom academic performance. Journal of Educational Psychology, 82(1), 33-40. https:// doi.org/10.1037/0022-0663.82.1.33

Rashtchi, M. (2007). A pathway toward critical thinking through cooperative writing in an English college course in Iran. The Near and Middle Eastern Journal of Research in Education, 2(1), 1-11. https://doi.org/10.5339/ nmejre.2007.2.1 
Rashtchi, M., \& Jabalameli, B. (2012). How attitude, self-efficacy, and job satisfaction relate with teaching strategies? Issues in Language Teaching, 1(1), 189-224.

Rashtchi, M., \& Khoshnevisan, B. (2019). The developmental stages of teachers: A critical analysis. In B. J. Waynne \& C. Cobanoglu (Eds.). Advances in global education and research (Vol. 3; pp. 2-8). ANAHEI. https://scholarcommons. usf.edu/anaheipublishing/vol3/iss2019/1/

Rashtchi, M., \& Sadraeimanesh, F. (2011). Is debate a useful strategy in enhancing the reading comprehension and critical thinking of Iranian EFL learners? Theory and Practice in Language Studies, 1(4), 361-369. https://doi.org/10.4304/ tpls.1.4.361-369

Rodríguez, S., Núñez, J. C., Valle, A., Blas, R., \& Rosario, P. (2009). Auto-eficacia Docente, Motivación del Profesor y Estrategias de Enseñanza [Teaching self-efficacy, teacher motivation and teaching strategies]. Escritos de Psicología, 3(1), 1-7.

Sabah, S., \& Rashtchi, M. (2016a). An analysis of the impact of using reflective practices on the Iranian EFL teachers' critical thinking ability. Language Related Research, 7(7), 1-21.

Sabah, S., \& Rashtchi, M. (2016b). Critical thinking in personal narrative and reflective journal writings by in-service EFL teachers in Iran: Assessment of reflective writing. Journal of Teaching Language Skills, 35(3), 157-182. doi: $10.22099 /$ jtls.2016.3900

Schafersman, S. (1991). An introduction to critical thinking. http://www.freeinquiry.com/criticalthinking.html
Schwab, S. (2019) Teachers' student-specific selfefficacy in relation to teacher and student variables, Educational Psychology, 39(1), 4-18. https://doi.org/10.1080/01443410.2018.1516861

Shangarffam, N., \& Poshti, N. R. R. (2011). The relationship among EFL teachers' critical thinking, self-efficacy, and their perception of effective teaching. Journal of Applied Linguistics, 4(1), 175-207.

Swanson, P. (2012). Second/foreign language teacher efficacy and its relationship to professional attrition. Canadian Modern Language Review, 68(1), 78-101. https://doi.org/10.3138/ cmlr.68.1.078

Synder, G. L., \& Synder, M. J. (2008). Teaching critical thinking and problem solving skills. The Journal of Research in Business Education, 50(2), 90-99.

Tschannen-Moran, M., \& Hoy, A. W. (2001). Teacher efficacy: Capturing an elusive construct. Teaching and Teacher Education, 17(7), 783-805. https:// doi.org/10.1016/s0742-051x(01)00036-1

Zhang, H., Yuan, R., \& He, X. (2020). Investigating university EFL teachers' perceptions of critical thinking and its teaching: Voices from China. Asia-Pacific Education Researcher (Advance online publication). https://doi.org/10.1007/ s40299-020-00500-6

Zimmerman, B. (2000). Self-efficacy: An essential motive to learn. Contemporary Educational Psychology, 25(1), 82-91. https://doi. org/10.1006/ceps.1999.1016 


\section{APPENDIX A}

\section{Interview Questions}

1. Can you explain your idea about the critical thinking class?

2. What do you think about the topics?

3. What did you learn from the course?

4. Do you think the instruction could cause any changes in you? Can you talk about them?

5. Do you think the classes may affect the strategies and techniques you use in your classes?

6. Do you think the classes may have any impact on your classroom management in the future?

7. Do you think the classes may affect the way you usually treat your students?

\section{APPENDIX B}

A worksheet, session three: Read the following and explain your position.

1- One student cheats on the final exam. According to the school regulations, she should fail and repeat the course. However, her mother is a very close friend of yours. What is your decision?

2-Nick overhears two students bragging about having posted some inappropriate images of a female student online for a joke. Should he: A) Mind his own business B) Report the incident to the school principal C) Confront the boys and defend the student?

3- Sally's mother is suffering from a strange illness. She should take her to the doctor, but she doesn't have enough money. She finds a package of money in the street. What should she do?

4- You witness a bank robbery, and follow the perpetrator down an alleyway. He stops at an orphanage and gives them all the money. Would you: A) Report the man to police since he committed a crime B) Leave him alone because you saw him do a good deed. 
